\title{
REVOLUTIONS THAT AS YET HAVE NO MODEL: DERRIDA'S LIMITED INC
}

\author{
GAYATRI CHAKRAVORTY SPIVAK
}

Jacques Derrida. LIMITED INC: A B C. Baltimore: The Johns Hopkins Univ. Press, 1977; tr. Samuel Weber, in Glyph II, 1977.

In 1971, Derrida read a paper entitled Signature évènement contexte in Montreal. In 1972, it was included in his collection Marges de la philosophie [Paris: Minuit]. In 1977, in the first issue of Glyph, appeared its English version "Signature Event Context." The piece was followed by "Reiterating the Differences: A Reply to Derrida" by John Searle. In Derrida's essay the limits and implications of the philosophical strategy of J. L. Austin, the founder of speech act theory, are discussed. In his short reply Searle, himself a speech act theorist, picks out what in his opinion are some of Derrida's obvious mistakes and corrects them in a tone of high disdain. The piece in review is Derrida's response to Searle's "Reply," published simultaneously and under the same title in French and English. In French as a pamphlet, in English as a part of Glyph 2. In it, with a mocking show of elaborate patience, Derrida exposes Searle's critique to be off the mark in every way. Whereas Searle's essay is brusque and all too brief, Derrida's is long and parodistically courteous and painstaking.

1

I list below some of the issues around which Derrida cancels Searle's objections. I have not reproduced the actual tactic of refutation nor kept to the order in which they appear in Derrida's text:

A. The ethico-political implications of Austin's strategic exclusions. The concept of ordinary language in Austin is marked by an exclusion. Austin thought that parasitic discourse ("said by an actor on the stage, or ... introduced in a poem, or spoken in soliloquy") is part of ordinary language (Searle thinks Derrida is unaware of this), but only as a parasite, an extrinsic "part" that lives off of the whole [Glyph I, p. 190]. "The concept of the 'ordinary,' thus [since the parasite is not normally a part of normal ordinary language] of ordinary language to which he has recourse is clearly marked by this exclusion." $1 \mathrm{It}$ is this implicit definition of the norm that "reproduce[s] in a discourse said to be theoretical the founding categories of all ethico-political statements" [pp. 69, 240]. Although these exclusions "present themselves as . . . strategic or methodological suspension . . . they are fraught with metaphysical presuppositions" [pp. 5758, 227]. These metaphysical presuppositions inhere in the totalization

1/ have indicated the page number of the French text first, followed by a reference to the English translation. The references are henceforth incorporated in my text. The page references to this passage are $70 ; 241$. 
and idealization of the norm (the appropriate context) for a performative." 2 They also inhere in (a) describing "the relation of the positive [or standard] values to those which are opposed to them . . . as one of logical dependence," and (b) not realizing that "even if this were the case, nothing proves that it would be this relation of irreversible anteriority or of simple consequence" [pp. 64, 234]. "Distinguish[ing] clearly between possibility [that performatives can always be cited] and eventuality [that such possible events - citations, 'unhappinesses' - do indeed happen]," Derrida suggests that the protection and definition of a standard or norm which is obligatory to all ethico-political institutions is carried out by Austin's creation of a "theoretical fiction" - the logically prior norm or standard-"that excludes this eventuality in order to purify his analysis" [pp. 59, 60; 229, 230]. ${ }^{3}$ This does not mean, as Searle suggests, that Signature Event Context (Sec for short in Limited Inc) "suggested beginning with theatrical or literary [romanesque] fiction." But, Derrida continues, "I do believe that one neither should nor can begin by excluding the possibility of these eventualities: first of all, because this possibility is part of the structure called 'standard'" [p. 61, 231].

B. The Difference between Speech and Writing. The necessary possibility of these eventualities Derrida collectively and structurally calls "writing." Part of his argument in Sec is that speech act theory excludes Writing. In order to advance his argument he lists in that essay "the essential predicates in a minimal determination of the classical concept of writing" [Clyph I, pp. 181-182]. Invoking the Husserl of Logical Investigations [tr. J. N. Findlay (London: Routledge and Kegan Paul, 1970)] and The Origin of Geometry [tr. John P. Leavey (New York: Nicolas Hays, 1977)], he suggests that a certain Husserl articulated the suspicion that spoken utterances also shared these essential predicates of writing, and then went on to garner a place where Speech would shine forth alone. The detailed analysis of Husserl's itinerary is to be found in Derrida's introduction to The Origin of Geometry and in Speech and Phenomena, And Other Essays on Husserl's Theory of Signs [tr. David B. Allison (Evanston: Northwestern Univ. Press, 1973)]. Here Derrida focusses on the supposition that writing imitates speech but cannot share in the immediate link between speech and its context of production: "Every sign, linguistic or non-linguistic, spoken or written (in the current sense of this opposition), in a small or large unit, can be cited, but between quotation marks; in so doing it can break with every given context, engendering an infinity of new contexts in a manner which is absolutely illimitable" [Glyph I, p. 185]. Husserl takes care of this crisis through the general principle of phenomenological reduction, Austin through a programmatic, initial, and initiating exclusion. The rest of the argument I have summarized under $A$.

In Limited Inc, Derrida points out that Searle resolutely refuses to see that the former is attempting to rewrite the opposition Speech-Writing through what I shall call an ideology-critique (although Derrida would object to that phrase and call his critique ethico-political) of the interests of such an opposition. Among other things, Searle sees writing as transcription of speech, and sees text and (oral) context as distinct and different, whereas Derrida demonstrates that the principle of an undecidable and/or alterable (to the point of rupture) context is the condition of possibility of every mark, written or spoken.

\footnotetext{
${ }^{2} \mathrm{~A}$ performative speech act occurs when "it seems clear that to utter the sentence (in, of course, the appropriate circumstances) is not to describe my doing of what I should be said in so uttering to be doing or to state that l am doing it; it is to do it" []. L. Austin, How to Do Things with Words (Cambridge: Harvard Univ. Press, 1962), p. 6; italics author's].

3 Once such a "theoretical fiction" helps prove a point, author and reader tend to forget its situational fictiveness. Such is the case with Freud's "primary" - the adjective has the same normative ring as "standard" - "process": "It is true that, so far as we know, no psychical apparatus exists which possesses a primary process only and that such an apparatus is to that extent a theoretical fiction" [Sigmund Freud, "The Interpretation of Dreams," in The Standard Edition of the Complete Psychological Works of Sigmund Freud, tr. James Strachey (London: Hogarth Press, 1953), vol. 5, p. 603].
} 
Searle, then, refutes Derrida's views on speech and writing by "a too quick retranslation" of them into "a standard and trivial idiom" [p. 23, 188]. Now right from the start Derrida's project has been paleonymic, urging a rereading of old words such as "writing." More recently and by way of the work of Nicolas Abraham, a name for the sustained need to re-read every production of language that would take into account the permanent parabasis that Paul de Man calls "allegory" has been found: "anasemia" ["ME-psychoanalysis: An Introduction to the Translation of 'The Shell and the Kernel' by Nicolas Abraham," tr. Richard Klein, Diacritics 9, No. 1 (1979)]. The common problem with reading Derrida's work is often a disciplinary refusal even to entertain the possibility of undertaking such a re-reading; Searle is not free of this. But what we are speaking of here is an ignoring of even such obvious demands for scrupulousness as "a neologism in italics" [p. 23, 188]. Thus "the remains [restance, in French a neologism] of a grapheme in general" is retranslated into "permanence or survival or a 'written language' in the standard sense" [p. 23, 188]. As far back as the Grammatology, Derrida made it quite clear that, if one insisted that the being of writing was in the technique of making a system of tangible marks on tangible material, the grounds of difference between speech and writing could be quite legitimately sustained [Of Grammatology, tr. Gayatri Chakravorty Spivak (Baltimore: The Johns Hopkins Univ. Press, 1976), p. 56]. The pertinent question is, is this difference ground-ly [gründlich], irreducible? If this question is pushed, then a different answer seems to disclose itself: that there is a mark-ability (graphematicity) in speech and writing; and that it is by means of that mark-ability that something-never tangibly self-identical-is carried over in acts of speech and writing. That something, that minimal rather than total idealization that is different from itself in every case, is "the remains of a grapheme in general" and not "the permanence or survival of a "written language' in general," where the context remains irretrievably oral. "Once he had begun to neglect totally the necessity of passing from writing (in the standard sense) to the grapheme in general, an essential movement of Sec, Sarl could only go from one confusion to another" [p. 24, 189].

Searle's argument is that, although writing and speech are quite different in their relationship to context (indeed the latter might be considered the necessary context of the former), "intentionality "plays exactly the same role in written as in spoken communication" " [p. 27, 193]. This is a rough restatement of the Husserlian position, with which Derrida has never fully disagreed. But the status of intention is so large a part of Derrida's concerns in this essay, that I shall give it a separate rubric in my summary.

C. The Situation of Intention. The OED defines the term "Intention" as used in logic as follows: "the direction or application of the mind to an object." And here is a definition of Intentionality offered by Searle in a piece written well after the DerridaSearle exchange: "Intentionality- with-a-t is that property of the mind by which it is able to represent other things." 4 These are good places to begin in order to understand how, for the sake of emphasizing the similarity between speech and writing, Searle

\footnotetext{
${ }^{4}$ John R. Searle, "What Is an Intentional State?," unpublished manuscript, p. 17. It should be mentioned that, according to Searle, although he has "made fairly heavy use of the notion of representation . . . it is not essential to do so; one could make all the same points in terms of conditions of satisfaction or conditions of success of the Intentional states without explicitly using the notion of representation" [p. 25]. The piece as a whole is curious, open once again to every criticism presented in Limited Inc. Right at the end, however, there is this acknowledgment of aporia: "I do not believe it is possible to give an analysis of Intentionality. Any attempt to characterize Intentionality must inevitably use Intentional notions, and thus any such attempt will move within what I have elsewhere called the circle of Intentionality. * [Searle's note:] *Intentionality and the Use of Language, by J. R. Searle, forthcoming" [p. 25]. Later I shall speak of the circle of Interpretation and Heidegger's theory of a practice that might take it into account $(p .00)$. It is therefore worth noticing here that Searle's theory of disciplinary philosophical practice is to take everything "inside the circle" as self-evident and everything "outside" as irrelevant; a clear case of the exclusion of the other as such so that a normative interior can be defined.
}

diacritics/December 1980 
can write: "Writing makes it possible to communicate with an absent receiver, but it is not necessary for the receiver to be absent. Written communication can exist in the presence of the receiver, as for example when I compose a shopping list for myself or pass notes to my companion during a concert or lecture" [Glyph I, p. 200].

One response to this is contained in the answer that I summarize above: a possibility/eventuality is a necessary component of the structural definition of language [p. 0]. But Derrida also argues that the problem with classical concepts of intentionality is that they seek to actualize and totalize intentionality into self-presence and self-possession. It is this telos of the concept of intentionality that he is calling into question. In this context, it is not so much the ever-necessary possibility of the writer/reader's absence to the context, but the claim of the writer-reader's presence to himself in certain privileged contexts, that Derrida deconstructs, arriving back at the position that the necessary possibility of the absence of sender and receiver is the positive condition of possibility of "communication." We shall come back to this suggestion later. Here a gist of the point at issue will suffice:

To affirm . . . that the receiver is present at the moment when I write a shopping list for myself, and, moreover, to turn this into an argument against the essential possibility of the receiver's absence from every mark, is to settle for the shortest, most facile analysis. If both sender and receiver were entirely present when the mark was inscribed, and if they were thus present to themse/ves-since, by hypothesis, being present and being present-tooneself are here the same-how could they even be distinguished from one another? How could the message of the shopping list circulate among them? And the same hold force, a fortiori, for the other example, in which sender and receiver are hypothetically considered to be neighbors, it is true, but still as two separate persons occupying two different places, or seats. . . But these notes are only writable or legible to the extent that . . these two possible absences construct the possibility of the message at the very instant of my writing or his reading. [pp. 21-22, 186]

(This theme, that self-presence is irreducibly differentiated, is also to be found most extensively elaborated in Speech and Phenomena [especially in "The Voice that Keeps Silence"], a text that is closely related to Derrida's discussion of speech act theory. That relationship can be put simply as follows: two theories so seemingly disparate as Husserlian phenomenology and speech act theory share metaphysical presuppositions that make the latter's claim to pragmatic practicality somewhat dubious.)

Such a critique of intentionality does not, however, mean that intentionality must be "effaced or denied . . . as Sarl claims. On the contrary, Sec insists on the fact that 'the category of intention will not disappear, it will have its place'" [p. 30, 196]. Events, objects, acts, meanings - as "intended" by the ego-as well as intentions themselves might well be the effects of a desire precisely to have a self-identical intention that can produce interpretations. This is a limit that no concept of simple intention can cross, for such a desire cannot be thought in terms of a fully intending subject. It remains irreducibly structural. Yet, even as intention is situated within such limits, Derrida insists that it is these very limits, demarcating intention, that produce it, and allow it to function as such. If this point is missed, then Derrida is seen as an absurd nihilist. "What is valid for intention, always differing, deferring [différante] and without plenitude, is also valid, correlatively, for the object (signified or referent) thus aimed at. However, this limit, I repeat ('without' plenitude), is also the ('positive') condition of possibility of what is thus limited" [p. 29, 195]. If one is prepared to stand the Hegelian system on its head to displace the deconstructive cipher, one might compare this limiting possibility to the status of determination at the very beginning of The Science of Logic. Whereas in Hegel, by demarcating (limiting and making possible) Dasein out of Sein, de-termination also makes possible the production of the rigorous terminology of the self-critical language of philosophy; in Derrida the originary 
self-division of intention "limits what it makes possible while rendering its rigor or purity impossible" [31, 197].

One of the marks of Derrida's programmatic lack of rigor in Limited Inc is his elaborate and uneasy-making jokes. I shall speak at greater length about this strategy later. Here I will comment on the title of the piece and Derrida's use of the question of the copyright.

A footnote to the title of Searle's "A Reply to Derrida" discloses that the matter of Searle's essay is also a product of discussions among himself, $\mathrm{H}$. Dreyfus, and D. Searle. The text thus has a plurality of authorships which can be conveniently copyrighted under one signature or proper name. To keep this possibility ever in our minds, Derrida refers to the author of "A Reply to Derrida" as "Sarl" (S.a.r.l. - Société aux responsabilités limités - Limited Liability in English, Incorporated in American) and entitled his own piece Limited Inc. The recuperating of a plural, divided, heterogeneous, different-deferring intentionality under the rubric of a single self-present sovereign and generative intention has something in common with these (in Derrida's case ironic) procedures: "That Searle's seal should become, at once and without waiting for me, Sarl's seal, is not an accident. A little like the multiplicity of stockholders and managers in a company or corporation with limited liability, or in a limited, incorporated system; or, like that limit which is supposed to distinguish stockholders from managers" [pp. 28-29, 194]. Exactly the opposite of what happens to the "subject' in the scene of writing" - the I who, putatively, writes, and, having left her mark, leaves the scene. The classical concept of writing would say that, having removed her selfhood and her proper identity from the written page, the " $\mathrm{I}$ " of the writer (not merely of the "literary" text) allows a multiplicity of anonymous readers to invest it with their selfhoods. ${ }^{5}$ Derrida is suggesting that this subject in the scene of writing is also the subject in the very house of its own proper intention.

D. The Structural Unconscious. The picture of an irreducibly pluralized and heterogeneous subject can find its place in structuralist and post-structuralist interpretations of Freud. Such interpretations must see the conscious ego as an effect of the work of the "psyche" (whose outlines are, by that very token, more like an entangling network, structured by traces and postponements, than a neat geographical boundary), rather than as fully identical with the self as a whole. In speech act theory, however, "the identity of the 'speaker' or the 'hearer' [is] visibly identified with the conscious ego ... [and] the identity of an intention (desire or non-desire, love or hate, pleasure or suffering) or of an effect (pleasure or non-pleasure, advantage or disadvantage, etc.)" can be located in terms of "the conscious ego" [p. 44, 216].

Derrida's work is deeply marked by Freud: "in as much as it touches the originary constitution of objectivity and of the value of the object ... psychoanalysis is not a simple regional science" [Grammatology, p. 88]. Indeed, the debate with speech act theory relates precisely to the fact that, whereas Husserl, seeing the irreducible crisis of the instituted trace inscribed in the sign, had carefully written psychology out of phenomenology; speech act theory, seemingly introducing issues such as situationality and the human mind into the question of meaning, uses an intepretably over-simple model of both situation and mind -"a psychology of language (mechanistic, associa-

$5 /$ used my customary feminine pronoun here because I think of the writer, critic, philosopher and the like as "being like myself." But the reason why Derrida links (the historical position of) women with writing became immediately apparent. Since woman is constituted as the legal object of exchange, as evidenced by her so-called proper name(s), it is indeed in the house of her (legal) intention that she is by definition to be invested by other selfhoods in turn [see Claude Lévi-Strauss, Structuralist Anthropology, tr. Claire Jacobson and Brooke Grundfest Schoepf (New York: Basic Books, 1963), pp. $61-62$ and passim; Lévi-Strauss's disavowal of his own sexism is interpretable; Jack Goody, Production and Reproduction: A Comparative Study of the Domestic Domain (Cambridge: Cambridge Univ. Press, 1979); and Lesley Caldwell, "Church, State, and Family: the Women's Movement in Italy," in Feminism and Materialism: Women and Modes of Production, eds. Annette Kuhn and AnnMarie Wolpe (London: Routledge and Kegan Paul), pp. 75-82]. 
tionist, substantialist, expressivist, representationalist, pre-Saussurian, pre-phenomenological, etc.), more exactly a pre-critical psychologism" [p. 38, 205]. Derrida is rightly careful that his interest in psychoanalysis should not be confused with the therapeutic model of psychoanalytic practice-psychoanalysis as a regional science. Yet, since all of Derrida's work has been largely devoted to a critique of philosophy's need to adumbrate a fully conscious and self-conscious self-presence, it is curious that Searle seems to think that, according to Derrida, "intentions must all be conscious" [G/yph I, p. 202].

In response, Derrida carefully points out that "Sec's enterprise is in its principle designed to demonstrate such a 'structural unconscious' which seems alien, if not incompatible with speech act theory, given its current axiomatics" [p. 45, 213]. "Unconsciousness" in such an enterprise does not mean, as it does when Searle invokes unconscious intentions, "an implicit or potential reserve of consciousness, a kind of lateral virtuality of consciousness." It is the best available name ("for example and for the moment" [p. 46, 214]) for radical alterity. We have already discussed what it might mean to say that intentionality is irreducibly graphematic, that it is always already plural, an effect, heterogeneous, divided, and that that is precisely what allows it to work. Otherwise, identical with itself, "eyes closed tight, nostrils pinched shut, ears stopped up" it would be the "pure" body without organs, Undivided Mind. ${ }^{6}$ In order to work with such a graphematic intentionality, one needs a name for something that is at every moment divisively other yet indispensable to the production of the same, an "it" that resolutely leaves its track at every intended origin or goal. This "it" is not a transcendental unity, because with every heterogenous move of receiver, sender, and the world of meanings, it changes its shape and fills the (no)place that marks a contingent limit. It is not a conscious motor of things in general; therefore it had better be called the Unconscious.

(The irreducible structure of this radical alterity that is also the condition of possibility of ipseity is, as I have already remarked, sometimes called Writing by Derrida. Of late there has been considerable interest in the confusion and distinctions between Derrida's position and that of Paul de Man. It seems relevant to note that de Man's term for the irreducible oscillation of undecidability that is his last word is Reading, not Writing. Whereas writing in Derrida is both the trace-structure in general and empirical forms of writing in the narrow sense, even as it annuls that very opposition [Grammatology, p. 74], in de Man "the word 'reading' . . is . . . deprived of any referential meaning whatsoever" [Paul de Man, Allegories of Reading: Figural Language in Rousseau, Nietzsche, Rilke and Proust (New Haven: Yale Univ. Press, 1979), p. 77]. For Derrida, what one discovers in the Unconscious is not "the whole structure of language." On the one hand, conviction of that discovery might itself be a symptomatic effect; on the other, the structural unconscious is also that which stands in the way of any exhaustive concept of structure or language. What one discovers in the Unconscious is also not a reading-effect. If one examines the essential predicates of the classical concept of Reading-halfway between Speech and Writing-notions of control and privilege are not far to seek; even in reading "the flight of meaning" or an "allegory of unreadability," the putative agent restores that context which the classical concept of Writing, by its essential predication, loses as it preserves that in Speech which it can slavishly imitate. [For the Unconscious as the structure of language and a reading-effect, see Jacques Lacan, "The Agency of the Letter in the Unconscious or Reason Since Freud," in Ecrits, tr. Alan Sheridan (New York: Norton, 1977), p. 147; and Shoshana Felman, "Turning the Screw of Interpretation," Yale French Studies 55-56 (1977).]

\footnotetext{
${ }^{6}$ Gilles Deleuze and Félix Cuattari, Anti-Oedipus: Capitalism and Schizophrenia, tr. Mark Seem et al. (New York: Viking Press, 1977), pp. 37-38. In associating "body without organs" with "Undivided Mind" I am suggesting that there is an unacknowledged complicity with transcendental phenomenology in the schizo-analysis articulated by this otherwise extraordinary book. Deconstruction, by putting the trace-structure at the place of the origin or épochè, has repeatedly acknowledged a similar complicity. See especially Speech and Phenomena, pp. 153160 and Grammatology, p. 62.
} 
More specifically, such a structural unconscious also undermines the pigeonholing of meanings and speech acts. It can mark and undermine the conscious ego's decision to situate intended meaning in itself and for another conscious ego. "The specific law of . . . the displacement [Entstellung] of the signifier" that constitutes the production of a self-identical intentionality "governs those psychoanalytic effects that are decisive for the subject: such as foreclosure [Verwerfung], repression [Verdrängung], denial [Verneinung] itself" [Jacques Lacan, "Seminar on 'The Purloined Letter,' tr. Jeffrey Mehlman, Yale French Studies, 48 (1972), p. 40]. The ego's speech act in this reading might very well be a rubric indicating what it cannot say. If the unconscious is a place of possibilities of signification, the itinerary of the ego's selfconstitutive need to manufacture its sovereignty activates different clusters of signification with an irregular periodicity. In this sense, too, the radically other makes possible as it limits the ego's intention. Because speech act theory cannot recognize these limits it "excludes all other ultimate criteria than the distinct, determining, and determinable consciousness of the intentions, desires, or needs involved."

The rigorous distinction between promise and warning or threat, for instance, is established only by this expedient. Yet what would happen if in promising to be critical I should then provide everything that Sarl's Unconscious desires, for reasons which remain to be analyzed, and that it does its best to provoke? Would my "promise" be a promise, or a threat/warning? Searle might respond that it would constitute a threat to Sarl's consciousness, and a promise for the unconscious. There would thus be two speech acts in a single utterance. How is this possible? And what if the desire was to be threatened? And what if everything that is given to please or in response to a desire, as well as everything that one promises to give, were structurally ambivalent? [p. 47, 215]

It is within this framework that Derrida criticizes Austin's strategic exclusions:

For in the last analysis, seriously, who ever said that a dependent (logically dependent) element, a secondary element, a logical or even chronological consequence, could be qualified . . . as "parasitical," "abnormal," "infelicitous," "void," etc.? . . The common denominator [of all these attributes] is evidently a pejorative value judgment ... more or less a mere logical derivation. This axiological "more or less" cannot be denied. Or at least not without constituting, as far as Searle is concerned, the object of what is known [psychoanalytically] as a denial [dénégation]. [pp. 64-65, 235; translator's parentheses] $]^{7}$

It is also in terms of the vocabulary of the structural unconscious that Derrida chides Searle for suggesting that he, Derrida, assimilates writing and fiction: "It is imprudent to assimilate too quickly, more quickly than one can, what is not easily assimilable. Otherwise, what is produced is what certain psychoanalysts call incorporation without introjection: a sort of indigestion more or less desired by the unconscious and provoked by a parasite which remains unassimilable." 8

When Derrida makes a critique of the discipline of philosophy the structural unconscious is seen as oedipalized. This is, I think, because the history of disciplines in the West is the history of oedipalization as such. In Clas Derrida's disciplinary critique is in terms of the official denial of the son's desire for the mother and the

\footnotetext{
7"To negate something in a judgment is, at bottom, to say: 'This is something which I should prefer to repress"' [Freud, "Negation," Standard Edition, 19, p. 236].

8 In introjection, the ego is altered so that a lost object can be given up. In incorporation, the ego refuses to give up the object, and wants to keep it by swallowing it. The resulting "indigestion" is melancholia [Freud, "Mourning and Melancholia," Standard Edition, 14] or "cryptomania" [Nicolas Abraham and Maria Torok, Le Verbier de I'homme-aux-loups (Paris: Flammarion, 1976)].
}

diacritics/December 1980 
thematics of fetishism. Here it is in terms of the homoeroticism of the (patriarchal) disciplines, the jealously guarded relay of truth passing from father to son. If we regard the following examples as "merely a joke in poor taste," we overlook the insertion, in Derrida's works, of psychoanalysis into the exclusivist discipline of philosophy. It is an inter-disciplinary endeavor that would put the proprieties of the disciplinary subdivision of labor into question.

Searle scolds Derrida for hassling Austin over his exclusions; for Searle has himself now established a general speech act theory of fiction ["The Logical Status of Fictional Discourse," NLH, 5 (1975); cited in Glyph I, p. 208]. The complaint about exclusions no longer applies. Derrida points out that the relevant Searle essay appeared well after Sec and that it ends in the following inconclusive way: ". . there is as yet no general theory of the mechanisms by which such serious illocutionary intentions are conveyed by pretended illocutions" [p. 69, 240]. Derrida's critique of programmatic exclusions might still stand.

It is, however, upon the way in which Searle announces himself as carrying on Austin's work that Derrida comments:

As to the "general theory," Sarl would like Austin both to have had one... and also, having died too young, not to have really had ... one, so that the copyright of the "general theory" in the proper, literal sense . . could be the rightful property only of the more or less anonymous company of his sons. .. This is why - . . the paragraph beginning with "Once one has a general theory of speech acts . .." is . . . a masterpiece of metaphysical-oedipal rhetoric. Imagine the scene: Austin's will is about to be unsealed. Although the envelope has not yet been entirely opened, the lawyer of one of the sons begins to speak: "Once one has a general theory of speech acts. . . " Once? We still don't know if Austin had one or was going to have one. . . I sincerely regret that "Austin did not live long enough.". . But through my tears I still smile at the argument of a "development" (a word sufficiently ambiguous to mean both produce, formulate, as well as continue, in order to reach "detailed" answers), that a longer life might have led to a successful conclusion. [pp. 66-67, 237-238]

The disciplines; and they are inescapably patriarchal, would present themselves as disinterested if not meta-physical. A patriarchy, however, works according to the love-hate rules of the oedipal scene which it has spent its energy proclaiming to be the correct structural explanation of all human relationships. There is both the "parricide" - Austin could not have done it without me-and the dynastic pride-I am carrying on Austin's work.

In allowing the psychoanalytic argument to sweep from the irreducible structural unconscious in intentionality as such to the oedipal functioning of the disciplinary tradition, Derrida performs a critique of the disinterest that is supposed to inform all academic discussions as well as the history of ideas.

E. Iterability (Citationality, Parasitism). Over the years, even as he has been practicing paleonymy, Derrida has been deploying an alternate denomination for the method of metaphysics, disclosed or undisclosed, that inhabits the language of the human sciences. There are many names on this list. The most recognizable might be: the graphic of the trace rather than the logic of the simple origin; the graphic of differance rather than the logic of identity; the graphic of supplementarity rather than the logic of non-contradiction. Sec and Limited Inc add another: the graphic of iterability rather than the logic of repetition.

The substitution of graphic for logic is also an example of this alternate denomination. Derrida's method is not centered on the putative self-enclosed self-presence of the logos as the identity of voice-consciousness in the act of speech; it shares rather the structure of irreducible self-alterity carried by the backward and forward and 
many-planed tracing of intentions in writing. In other words, it seeks to be graphematic rather than logocentric. Hence its name is graphic rather than logic.

One of the corollaries of the structure of alterity which is the revised version of the structure of identity is that every repetition is an alteration. This would put into question both a transcendental idealism that claims that the idea is infinitely repeatable as the same and a speech act theory that bases its conclusions on intentions and contexts that can be defined and transferred within firm outlines. Iterability is the name of this corollary: every repetition is an alteration (iteration).

But repetition is the basis of identification. Thus, if repetition alters, it has to be faced that alteration identifies and identity is always impure. Thus iterability-like the trace structure-is the positive condition of possibility of identification, the very

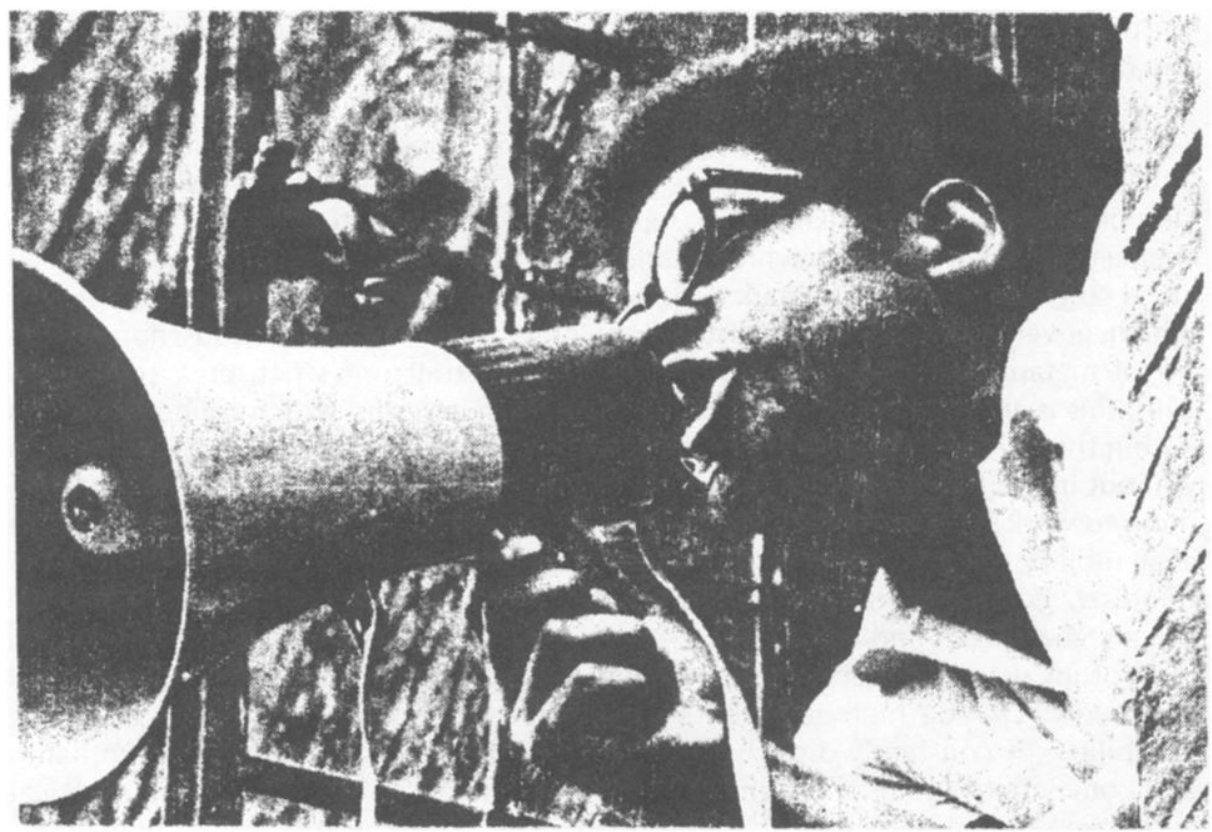

thing whose absolute rigor it renders impossible. It is in terms of iterable (rather than repeatable) identities that communication and consensus are established: "What is this consensus? what convention will have insured up to now the contract of a minimal agreement? Iterability" [p. 36, 203]. Searle [Sarl] seems in agreement with Derrida on this very last issue. He is not, however, ready to grant the radicality of Derrida's position. "Iterability is [not] necessarily tied to convention, and ... is [not] limited by it" $[$ p. 74, 246]. Since every identification is an iteration, the "natural," "spontaneous," "intended" utterance is as iterable as the conventional. "Iterability is precisely that which-once its consequences have been unfolded-can no longer be dominated by the opposition nature/convention" [p. 74, 246].

Thus the exchange in the "normal" speech act cannot, strictly speaking, be structurally differentiated from one where both intention or context are artificial or infelicitous. They are two cases of the alteration in repetition: iteration. "Rather than oppose . . . iteration to the non-iteration of an event, one ought to construct a differential typology of forms of iteration. ... In such a typology, the category of intention will not disappear, it will have its place, but from that place it will no longer be able to govern the entire scene and system of utterance" [Glyph I, p. 192]. Such a necessarily non-exhaustive typology would include all the "non-serious" uses of the performative mentioned by Austin - such as citation and the literary or theatrical parasitic use. Acknowledging "the structural iterability of the mark" - the grapheme, the unit of writing rather than of speech-one must take into account that "language 
can always 'normally' become 'abnormally' its own object" [p. 54, 223]. The possibility of citing or theatricalizing is structurally inherent in every "intended" speech act.

Yet this does not mean to privilege fictional and theatrical uses of speech acts as commonly understood. Just as there is no homogeneous and totalizable intention generating the utterance, so also can it not be advanced that the utterance is simply autotelic as such. ${ }^{9}$ It is rather that, among the many heterogeneous elements that constitute the speech act with traces leading back and forth, the iterable non-selfidentical intention and context as well as the "parasitic" use are structural moments. The "theater" does not win out over "real life." The two are seen as indistinguishably and structurally implicated. "As though literature, theater, deceit, infidelity, hypocrisy, infelicity, parasitism, and the simulation of real life were not part of real life!" [p. 62, 232]. Iterability "blurs the simplicity of the line dividing inside [real life or fiction] from outside [fiction or real life], the order of succession or of dependence between the terms [privileging real life or literature], prohibits (prevents and renders illegitimate) the procedure of exclusion" [p. 64, 234; italics Derrida's]. This is the point at which this reviewer's summaries began.

Iterability "itself" cannot be privileged as a "transcendental condition of possibility" [p. 72, 244] for fiction, theater, parasite, citation and the like. Whereas repetition presupposes a full idealization (repeatability as such), iterability entails no more than a minimal idealization which would guarantee the possibility of the re-mark. But since "the iterability of the mark does not leave any of the philosophical oppositions which govern the idealizing abstraction intact (for instance, serious/non-serious, literal/metaphorical or ironic, normal/parasitical, strict/non-strict, etc." [p. 42, 209210], this is an impure idealization, a contradiction in terms, which cannot be caught within the either-or logic of non-contradiction. "No process or project of idealization without iterability, and yet no possible idealization of iterability" [pp. 42-43, 210]. In order to work with a non-transcendental non-logical (non)-concept (or graphic), such as iterability, one must think a great change of mind-set. Of course a mere change of mind-set, however great, will not bring about revolutions. Yet, without this revolutionary change of mind, revolutionary "programs" will fall into the same metaphysical bind of idealized and repeatable intention and context that Derrida plots in speech act theory. Derrida hints as follows at the practical possibilities of the graphic of iterability: "it constantly disturbs, subverts, and displaces the limit [between nature and convention]. It has an essential rapport with the force (theoretical and practical, 'effective,' 'historical,' 'psychic,' 'political,' etc.) of the deconstruction of these oppostional limits" [p. 74, 246].

Our own arena of practice is the production of theoretical discourse. This practice would be significantly altered if it recognized that theoretical discourse were irreducibly iterable. (It is a mark of the necessary "impurity" of a graphic that such recognition must come through that very conscious intention that the graphic calls into question):

What must be included in the description, in what is described, but also in the practical discourse and in the writing of that describing [décrivante-dewriting-undermining graphematicity by its attempt at unitary idealization] description, is not merely the factual reality of corruption and of alteration [de l'écart], but corruptability (to which it would be better henceforth not to give this name, which implies generally a pathological disfunction, a degeneration or an ethico-political defect) and dissociability, all the charac-

9Derrida's re-writing of Mallarmé's famous sentence, at the end of "The White Mythology," problematizes the position that language may be purely self-referential or autotelic. Mallarmé: "I say: a flower! and out of the forgetfulness to which my voice relegates any contour, in so far as it is something other than known calyxes, musically arises, the idea itself and sweet, the one absent from all bouquets [a word Derrida playfully "translates" as "anthology"] [Crise de vers]. Derrida: "There is always absent from any garden, a dried flower in a book; and because of the repetition in which it is endlessly spoilt [s'abŷme], no language can reduce to itself the structure of an anthology" ["White Mythology: Metaphor in the Text of Philosophy," tr. F. C. T. Moore, New Literary History, 6, No. 1 (1974), p. 74]. 
teristics tied to iterability which Sec proposed to account for. That can only be done if the "-bility" ... is recognized from the inception [dès l'entame] as broached and breached [entamée] in its "origin" by iterability. [p. 50, 218219; all but the first parenthesis, translator's]

A case of such altered practice is a section title in Sec: "Parasites. Iter, Of Writing: That It Perhaps Does not Exist." The page and a half [52-54, 224-226] where Derrida explicates himself are spectacular. Briefly, the lines of argument are as follows: Derrida's sub-title grafts itself on a Cartesian "original," De essentiâ rerum materialum; et iterum de Deo, quod existat [On the Essence of Material Things: And Likewise of God, That He Exists]. This is not just an "example" of invoking a "presence" through a deliberate citation. Descartes himself is also iterating; for this is a "repetition" (iteration) of an earlier Cartesian argument for the proof of Cod's existence. But it is not even merely a case of iteration, for the word "iter" is also mentioned. In that sense it is also "literally" an "iter"-ation. Thus the text mimes a deconstruction of the oppositions between literal and figural, use and mention. ("Iter" is not only "simulacrum" - like wise-as the English translation of the subtitle suggests. It is also "alter" or other. A corroboration of Derrida's insistence that the suppression of othering or iteration carries an ethico-political charge is borne out by the fact that, in the usage of the modern languages of Northern India, "itara" - other - means not only "inferior" but is also the name of the untouchable castes.) Derrida is questioning the "allegorical" and "literal" in terms of his own reading of Descartes, as well as in reading "as such":

The iterability of the proof (of Cod's existence) produces writing, makes one write [fait écriture, fait écrire-italics Derrida's] and draws the name of God (of the infinite Being) into a graphematic drift [dérive] [a double take by Descartes, in this case, on an earlier text of his own] that forbids (for instance) any decision as to whether God is more than the name of God, whether the "name of Cod" refers to God or to the name of God, whether it signified "normally" or "cites," etc., God being here, like/as [comme] writing, what at the same time renders possible and impossible, probable and improbable the purity of the opposition between the "normal" and, for example, the citational or the parasitical, the serious and the non-serious, the strict and the non-strict or less strict. [p. 55, 225]

So Derrida chooses to memoralize this sub-title in his own because it launches the name of God into the double take of writing. Derrida puts writing in the place of God: "Iter, Of Writing." But writing is not in opposition to God. In order to let the opposition play, God as Logos "certainly should exist." Only of writing as graph can it be said "that it perhaps does not exist." It does not certainly have being as defined by the either-or structure of ontological discourse (the language of the logic of being)..$^{10}$

It should perhaps be remarked here that, if a reading such as this were to be translated to the social text, it would require an extremely sharp eye for "history." Clear-cut oppositions between so-called material and ideological formations would

10 It should be repeated that this displacement of God by writing is another case of the placing of the trace-structure at the origin or the transcendental condition of possibility of which I write in note 6. For another case, one might look at how Derrida elsewhere launches Descartes' "proper name" (as authoritative as Cod in this example) into the drift of writing - to describe the impossibility of making a proper beginning outside of the chain of metaphoricity. The "master-metaphor" in that argument is the famous Cartesian "pilot in his ship," which Derrida uses against the Cartesian grain. The sentence that interests me runs as follows: "That is why just now I have been moving from digression to digression, from one vehicle to another without being able to brake or stop the autobus [transportation is metaphora in modern Creek]" ["The Retrait of Metaphor," Enclitic, 2, No. 2 (1978), 7; italics mine]. The italicized passage, indicating the impossibility of authoritative origins, runs in French: "d'écart en écart." If one makes a liaison between the first two words, one gets the proper name of the celebrated philosopher, its nominative articulation-an accident in itself-dependent upon the humble syncategoreme "en." 
be challenged as persistently as those between literal and allegorical uses of language. The sedimentation and investment of history as political, economic, sexual "construction" would be seen as irreducible. Material objects, and seemingly non-textual events and phenomena would have to be seen not as self-identical but as the space of dispersion of such "constructions," as the condition or effect of interminable iterations. Yet, since iterability fractures intention as well, a simple stockpiling of "authoritative analyses from this point of view" without intervention in enabling and disabling autoand disciplinary-critiques would be beside the point.

II

"The matter we are discussing here concerns the value, possibility, and system of what is called logic in general. The law and the effects with which we have been dealing, those of iterability for example, govern the possibility of every logical proposition. . . . No constituted logic nor any rule of a logical order can, therefore, provide a decision or impose its norms upon these prelogical possibilities of logic" $[65,235]$.

This seems an iteration of Heidegger's placing of "assertion" [Aussage]-the logical language of philosophical predication - as "aris[ing] from circumspective interpretation" [Being and Time, tr. John McQuarrie and Edward Robinson (New York: Harper and Row, 1962), p. 200]. "The basic stock of 'categories of signification,' which passed over into the subsequent science of language, and which in principle is still the standard, is oriented towards discourse as assertion. But if on the contrary we take this phenomenon in the fundamental principle of primordiality and breadth of an existentiale, then there emerges the necessity of settling the science of language on foundations which are ontologically more primordial" [Heidegger, p. 209].

Given his own comments on the "metaphysical-oedipal rhetoric," it is interesting that Derrida has recently disclaimed continuous filiation with Heidegger in his Reply to Ricoeur:

Ricoeur inscribes his entire reading of "White Mythology" in dependence on his reading of Heidegger..., as if I had attempted no more than an extension or a continuous radicalization of the Heideggerian movement. . . . Everything takes place as if I had only generalized what Ricoeur calls Heidegger's "limited criticism" and as if I had stretched it inordinately, beyond all bounds. A little further on, in the same gesture of assimilation,

Ricoeur resorts to the figure of a "theoretical core common to Heidegger and to Derrida." . . . This continuist assimilation or setting into filiation surprised me. . . I see myself the object, after being assimilated to Heidegger, of an objection whose principle I had myself formulated previously. ["The Retrait of Metaphor," p. 13]

What follows makes no pretense at figuring out the relationship between Heidegger and Derrida. It is simply yet another summary or checklist of certain moments in Heidegger that bring Limited Inc to mind, followed by a few suggestions as to how Derrida might be different. To interpret the possibility of a metaphysicaloedipal disclaimer would call for a different strategy.

My reading of Heidegger is somewhat anthropologistic. I have been guided by Derrida's insight: "We see, then, that Dasein, if it is not man, is not, however, other than man" ["The Ends of Man," Philosophy and Phenomenological Research 30, No. 1 (1969), p. 48]. Although I am attempting to show that a Derridian practice would question "the name of man as Dasein," my reading of Derrida might also seem anthropologistic. I think I must insist that a deconstructivist position cannot reduce out anthropologism fully. Like the paradox of minimal idealization (see p. 00), the trace of anthropologism obstinately clings as restance to the practice of deconstruction.

Heidegger shows that philosophical assertion, the ideal of scientific rigor and common sense share a certain exclusivism or restriction. 
Of philosophical assertion, Heidegger writes: "Determining [or predicating] does not first discover the seen . . . as such; it rather restricts the seen as a mode of showing, in the first instance, to that which shows itself . . . as such so that by this expressive [ausdrücklich] restriction of our view, the manifest may be made expressively manifest in its determinateness [Bestimmtheit]" [Heidegger, p. 197]. ${ }^{11}$ I invoke Hegel's notion of determination on p. 00. The title of the second chapter in Hegel's Science of Logic is "Dasein" - generally translated as "Determinate Being." Heideggerian Dasein would not take the philosophical mode of assertion as its privileged determination. In looking for a pre-predicative place of Dasein's operation, Heidegger looks forward to the Derridian project. Indeed, Derrida's critique of speech act theory can be put this way: speech act theory attempt to go beyond the privileged philosophical mode of predication, which Austin calls the constative. Yet, in assigning a totalizable and homogeneous intention and context to the performative, it falls prey to the same metaphysical presuppositions that the constative shares.

Of scientific rigor and common sense, Heidegger writes as follows: "Because understanding, in accordance with its existential meaning, is Dasein's own beingcapacity [Seinkönnen], the ontological presuppositions of historiological [historisch] knowledge in principle go beyond [übersteigen] the idea of rigor held in the most exact sciences. Mathematics is not more rigorous than historiology [Historie], but only narrower, because the existential foundations relevant for it lie within a narrower range" $^{\prime \prime}$ [Heidegger, p. 195]. Derrida's suggestion about the language (theory and practice) of the human sciences is that the condition of the possibility of its being (its ontological pre-suppositions)-iterability - is what denies it rigor. In that Heidegger relates these ontological presuppositions to the impossibility of a fundamental ontology, he remains recuperable to a Derridian idiom. In that he describes this relationship as a principled transcendence he seems to sketch a privileging of which Derrida would be as critical as of the metaphysical underpinnings of speech act theory.

Comparably, of assertion as communication, Heidegger writes: "As something communicated [als Mitgeteilte], the asserted [das Ausgesagte] can be 'shared' ['geteilt'] by others with the person making the assertion, without his having to have the entity which he has pointed out and determined within graspable and visible proximity [ohne dass sie selbst das ausgezeigte und bestimmte Seiende in greif- und sichtbarer Nähe haben]: The asserted can be passed along in 'further retelling.' . . . But at the same time, what has been pointed out may become veiled again in this further retelling" [Heidegger, p. 197]. One could find the itinerary of iterability here. But only the labor of interpretation can establish that the Heideggerian terms "entity," "pointing out," "grasping and seeing," "becoming veiled" are untotalizable, and that Heidegger is contrasting the definiteness of determination to something irreducibly indefinite. Derrida confronts "communication" head on in Sec, and suggests that determinations are themselves indeterminate: "If communication possessed several meanings and if this plurality should prove to be irreducible, it would not be justifiable to define communication a priori as the transmission of a [determinate] meaning, even supposing that we could agree on what each of these words (transmission, meaning, etc.) involved" [Glyph I, pp. 172-173].

Yet when Derrida writes: "However, even to articulate and to propose this question I have had to anticipate the meaning of the word communication: I have been constrained to predetermine communication as a vehicle" [Glyph I, p. 172], we cannot but sense the strong Heideggerian theme of the pre, the inevitable fore-structure of interpretation and the as-structure of understanding.

The Heideggerian Dasein, structurally in between this pre- and the following "post-," is the scene of non-self-identity: "Dasein is always 'beyond itself' [über sich hinaus], not as a way of behaving towards other entities which it is not, but as Being

11 If the choice of metaphors or examples in a conceptual text is not fortuitous, it should be noticed that Heidegger's illustration for the thing escaping predication or assertion is "the hammer itself." Is it fanciful to recall that, in The Twilight of the Idols, Nietzsche wished to "philosophize with a hammer?" 
towards the being-capacity which it is itself. This being-structure of the essential 'is an issue,' we shall denote as Dasein's 'Being-ahead-of-itself'" [Heidegger, p. 236; parenthesis translator's]. Such a principle of an irreducible non-self-identity is indeed Derrida's theme as well. Yet the relationship between the two philosophers is not one of continuous radicalization. It is rather the prying open of the Heideggerian text (and thus being discontinuous with it) by turning the principle of non-self-identity into iterability, which will grant neither a totalizable horizon nor homogeneity. It is here that the structural unconscious plays its role. Lacking such a category, the closest Heidegger comes in Sein und Zeit to a practical recognition of alterity is: "The layingbare of Dasein's originary being must rather be wrested from Dasein as a countermove [im Cegenzug] to the falling ontico-ontological tendency of interpretation" [Heidegger, p. 359].

It is in this matter of practical imperatives that Heidegger again looks forward to Derrida. Understandably, Heidegger does not see his own practice as "express[ing] a priority of the 'practical' attitude over the theoretical" [Heidegger, p. 238]. Yet in suggesting that "care [Sorge] . . a always caring [Besorgen] and caring-for [Fürsorge], even if only privately ... as an originary structural totality, lies 'before' [vor] every factical 'attitude' and 'situation' of Dasein," he is introducing the category of what might be called affect in general into ontology - a category that would conventionally find no place there, and that is still resisted by disciplinary cognitive interpretations of "care." Here too the structural unconscious displaces the reserves of Heidegger's thought. For Derrida, a category such as care cannot be neatly distinguished from other desiring affects such as "willing, wishing, urge, addiction" [Heidegger, pp. 238239]. Care can no longer be "ontologically 'earlier' within the 'full ontological horizon,'" for the thought of a full horizon would itself be contained within a philosophical affect.

Following this pattern of a deconstructive insight recuperated by an idealist blindness which Derrida has noticed in Heidegger since "Structure, Sign, and Play," the Heideggerian imperative for the authentic ontology of Dasein is: "Our efforts must rather aim at leaping into this 'circle,' originarily and wholly, so that we ensure a full view of Dasein's circular Being, even as a Daseinanalysis is broached" [Heidegger, p. 363; italics mine].

The circle in question is the impossibility of ever producing an interpretation and an understanding that are free of the existentially (though not empirically) motivated structures of as- and for- and beyond. "Historiology [Historie; what one might call the human sciences] must then come to terms with [abfinden] less rigorous possibilities of knowing [than scientific knowledge]," for "according to the most elementary rules of logic, this circle is a circulus vitiosus" [Heidegger, p. 194]. Science and common sense attempt to ignore this vicious circle. But "what is decisive is not to get out of the circle but come into it the right way" [Heidegger, p. 195]. It is in search of this right way that the Heidegger of Being and Time recognizes the ontological priority of care and proposes the leap. But here too a certain complication must, at least, be set down; "the ontologically elemental totality of the care-structure cannot be traced back to some ontical 'arch-element'" [Heidegger, p. 241].

To engage in analytical and interpretative activity with a full awareness of the circularity of determinate Being is then the articulation of authentic Dasein. In its broad outlines, this might seem sympathetic to the deconstructive project. In its detail, a certain re-writing becomes necessary. Iterability, as I have indicated, takes away the possibility of a full awareness. It re-writes the enclosure of the circle as, at best, an ellipse that stands in for the impossibility of pure or geometric figuration. The end of the project - the articulation of authentic Dasein - becomes impossible because authenticity-Eigentlichkeit (ownness, proper-ness, literalness, true-ness) - is at the limit a denial of the lack of self-identity which Heidegger himself posits and which in Derrida becomes irreducible. In place of the leap into the circle comes the need to "get used to the idea that, knowingly or not, willingly or not, [we] deal fictively with things which are marked in advance by the possibility of fiction, either as the iterability 


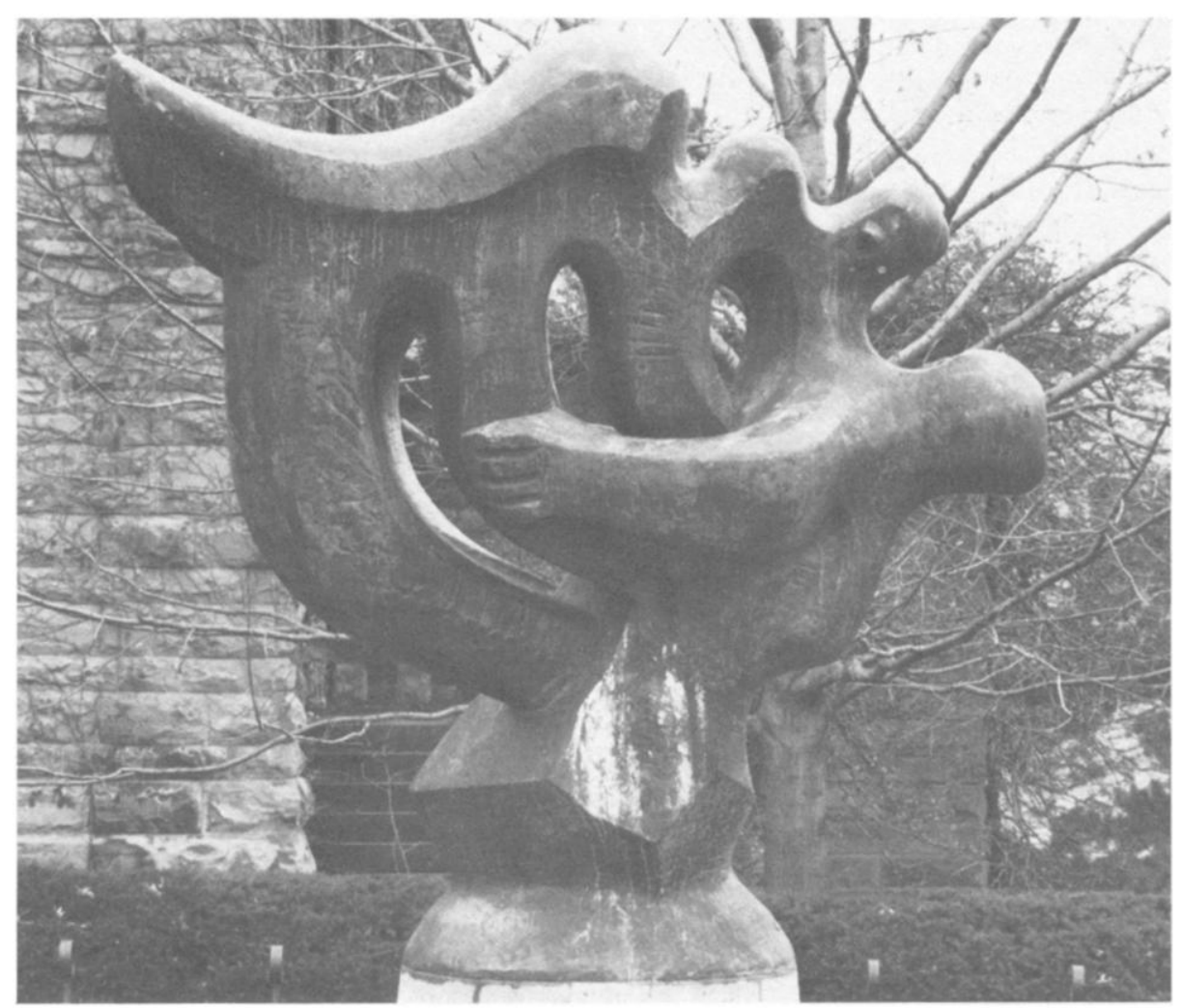

of acts or as the system of conventionality. [We] cannot therefore de-limit the objectfiction or the object-parasite, except by a counter-fiction" $\left[\right.$ p. 72, 243]. ${ }^{12}$

(If this were an extended discussion of the trace-structure as condition of possibility and denial of rigor, one would direct one's attention to Heidegger's "The Origin of the Work of Art" [in Poetry, Language, Thought, tr. Albert Hofstadter (New York: Harper Colophon, 1975), pp. 15-87], one of Derrida's texts in "The Retrait of Metaphor." In these pages I have followed my surmise that, if one wished to plot the dynamics between Heidegger and Derrida in terms of a theory of (the) practice (of theory and so on), one could do worse than to examine the trace-here iterability - in terms of the Heideggerian ontico-ontological difference; a possibility suggested by Derrida himself in "Differance" [in Speech and Phenomena, p. 130 and passim].)

It should by now be clear that Derrida's invocation of "fictions" does not mean indenturing the discipline of philosophy to the discipline of literature. One might think of it perhaps as deconstructing the Hegelian opposition and ranking between the ethical and the aesthetic. That particular undertaking can be located in the analysis of Sittlichkeit in the left-hand column of Glas.

\section{III}

It is well known that Heidegger must rewrite nearly every word in the vocabulary of philosophy because he has seen through the rigor of philosophical language. It is

12 The irruption of such fictionality in the most serious categories of class analysis may be seen in the "abnormal" use of strikes made by the microstructural hierarchy of the working class. "The trick of, say, bribing two days' wages in the shape of OT [overtime] by Class III employees easily wins the support of Class IV staff in a day's 'successful' token strike" [Timir Basu, "Calcutta Notebook," Frontier 12, No. 36 (1980), 5-6]. If a macrostructural class-theory sees this as a sign of working class solidarity, it should and should not be mistaken. Quite appropriately, Basu continues, "thus, withdrawal of labour in any form or strike does not necessarily signify the workers' inbuilt strength." The next crucial step is to acknowledge that such parasitic fictions will consistently norm the majestic calculations of theory. 
possible to situate Derrida's increasing experimentation with language in a comparable impulse. As I remark above, he seems to be bent upon coining a multiplicity of terms for more or less the same thing: trace, supplement, differance, parergon, retrait, iterability - and many more. He also twists and pluralizes style and typography to account for the fact that a unitary message about a unitary object from a unitary author to a unitary reader is what his writing calls into question.

Where Derrida is strikingly different from Heidegger is in his entertainment of the "non-serious." (Here one might speculate upon his relationship to Nietzsche.) Since Limited Inc is an especial critique of pure seriousness as ethico-political centralization, the non-serious element is most pertinent here.

The mingling of serious and non-serious in a critique of seriousness is well exemplified in the following passage:

[Iterability] carries an internal and impure limit that prevents it from being identified, gathered to itself, or in its presence [en soi ou auprès de soi], from being reappropriated, just as it forbids the reappropriation of that whose iteration it nonetheless broaches and breaches [entame]. But under such conditions, one will reply, no scientific or philosophical theory of speech acts in the rigorous, serious, and pure sense would be possible. That is, indeed, the question. . . . A theoretical discourse of this (classical, traditional) type must indeed tend, in accordance with its proper ethics and teleology, to produce speech acts that are in principle serious, literal, strict, etc. The only way that speech act theory might escape this traditional definition would be for it to assert (theoretically and practically) the right of its own speech acts not to be serious, etc., or rather not simply serious, strict, literal. Has it done this up to now? Might it have escaped me? In all seriousness, I cannot exclude this possibility. But am I serious here? . . The drama of this family of theoreticians: the more they seek to produce serious utterances, the less they can be taken seriously. It is up to them to seize this opportunity or to transform this infelicity into delight [jouissance]. [pp. 43-44; 210-212]

"But am I serious here?" Within the disciplines of philosophy and literary criticism, that is the question that many readers of Derrida have not been able to answer. Yes, Derrida is "making fun of" Searle; and "one does not write philosophy like that." But also, to repeat, the charge is precisely against that seemingly impenetrable but ultimately perhaps even stupid seriousness of the academic intellectual; that is the "condition or effect-take your pick" of ethico-political repression. And one should give Derrida the benefit of the doubt that, when he asks such a question it does not only mean "you can't tell, can you?" but that, "given the implications of my critique, I can't tell either; yet I will take my stand and make the critique nonetheless." It is a critique of the vanguardism of the theoretician. "It is right also that philosophy should be called knowledge of the truth. For the end of theoretical knowledge is truth, while that of practical knowledge is action (for even if they consider how things are, practical men do not study the eternal, but what is relative and in the present" [Aristotle, "Metaphysics," in The Basic Works of Aristotle, ed. Richard McKeon (New York: Random House, 1941), p. 712].

It is all the more poignant that since he is himself caught up in an international academic life-style, Derrida can behave as a non-serious marginal (given that his model is the criminal or defendant rather than the revolutionary) only in limited ways. ${ }^{13}$ I should insist that, to undermine the plausibility of one's arguments, to give the reader the ingredients for "situating" one's own "intention," remains a considerable risk. (Indeed, such an undermining makes many devoted readers wonder why Derrida

${ }^{13}$ His involvement with GREPH (Groupe de recherches sur l'enseignement de la philosophie-a multi-level national group of students and teachers in the institutional pedagogy of philosophy - should be mentioned. "For GREPH - there is no Philosophy with a capital P [il n'y a pas la philosophie]" [Qui a peur de la philosophie, eds. Sylviane Agacinski et al. (Paris: Flammarion, 1977), p. 5]. 
has turned "autobiographical," why he does not rigorously "deconstruct texts" any more.) It is a sign of the dynamism and power of the ideology that Derrida questions that this undermining can be recuperated into varieties of esoteric game-playing.

So much said, let me once again tabulate. I have spoken already of the significance of the thematics of the copyright, and the argument-if that is indeed what it is - about the oedipal metaphysics of the discipline of philosophy. Apart from these, one of the most noticeable items of non-seriousness in Limited Inc is that its sections are alphabetized. Its subtitle is "abc," which in French is pronounced abaissé-laid low. The inplications are obvious. "ABC" might also mean a primer, as in the following passage: "One of [Sec's] conventions which, like all others, cannot be rigorously justified, supposes the knowledge of certain a b cs of classical philosophy. .." [p. 73; 244]. In which case what we read might be intended as a primer of how to bring down the incorporation of the copyrighted liability organization that is the philosophical establishment. Further, the masquerading of the authority of the alphabet, the representative of phonographic writing in the narrow sense, might be to polarize the absurdity of accepting the authority of the "representative" of speech as the generative moment of voice-consciousness, as the explanatory speech-act convention, or yet as the determining sovereign intention. We are caught up short when, at the end of the next to the last section Derrida writes: "And, for the second time, I am going to conclude a bit abruptly, since I see that all I have left is the letter $z^{\prime \prime}$ [77; 249]. I should add, of course, that I cannot guarantee Derridian authorization for any of these meanings.

After abc, d occupies itself with the critique of the legal copyright to one's own words and mimes citationality by testing the seriousness of "Copyright ${ }^{\circ}$ by John D. Searle" as it is plausibly placed between more and more quotation marks. Derrida also tests the status of the signature as a man's mark by examining its every implication and reproducing "his own" in various ways.

Now these are, of course, "serious" demonstrations of Derrida's argument. But they are also, and unmistakably, high class tomfoolery. And, in that at least ambivalent tone, Derrida begins $f$ : "Let's be serious"; since it is only the "serious" tone of the performative that Austin will consider-and non-serious, parasitic, marginal uses (like mischief in a philosophical essay, even if it might have its point)-will be excluded. Readers will by now be prepared to read the following passage as more than a rhetorical flourish: "Faced with this speech act ('let's be serious'), readers may perhaps feel authorized in believing that the presumed signatory of this text is only now beginning to be serious, only now committing himself to a philosophical discussion worthy of the name, thus admitting that he had not done so yet." Derrida does not decide if such a feeling would be correct or not but goes on to say, in the next paragraph: "But let's be serious. Why am I having such difficulty in keeping my seriousness in this debate, to which I, in turn, have been invited? Why did I take such pleasure in accepting this invitation? Nothing compelled me to accept, and I could have-the temptation could have been strong-suggested to interested readers that they simply reread Signature Event Context" $[$ p. 7; 168-169]. Here the possibility that the structural unconscious might waylay every so-called conscious intention is directed at Derrida himself. It cannot, of course, be more than a question, because the Unconscious is another name for the it that is inaccessible to, yet broaches and breaches the I. Another theme that runs throughout Limited Inc is also touched upon here: that Searle unwittingly demonstrates many of the arguments of Sec and that his "Reply to Derrida" is thus a case of citationality.

To the question - but are we to look for such serious implications in such undisciplined language? - the answer is yes. To introduce the non-serious, to welcome the margins of the production of philosophic discourse - that is the intent of this disciplinary critique. These are the practical implications of passages such as the following: "What these 'fronts' [continental as opposed to Austinian philosophy-Searle's distinction; Derrida uses the word also in the sense of 'clandestine masks'] represent, what weighs upon them both, beyond this curious chiasmus, are non-philosophical forces. They must indeed be analyzed" [p. 10;172]. And, "it is because of this that I agree 
with Sarl that the 'confrontation' here is not between two prominent philosophical traditions' but between the tradition and its other, an other that is not even 'its' other any longer. But this does not imply that all 'theorization' is impossible. It merely delimits a theorization that would seek to incorporate [both in the psychoanalytic and the economic senses] its object totally but can accomplish this only to a limited degree" [p. 43; 211].

Thus it is (not) merely impertinent to acknowledge what generally remains tacit: that the academic game is played according to rules that might not pertain altogether to the disinterested intellect. I have attempted to give a sober account of the structural unconscious in the first part of this essay. I remarked there that it seemed unusual that Searle should accuse Derrida, whose work is profoundly complicit with the general morphology of psychoanalysis, of not acknowledging the unconscious. Derrida comments upon it in the following way: "What a fake-out, leaving me flat-footed in the camp of those insufficiently aware of the unconscious! . . For [my translator's] benefit let me specify that, ever since my adolescence, I have understood the word above all as a soccer term: an active ruse designed to surprise one's opponent occupied in another direction" [p. 45, 213]. That Derrida "knows" that Searle is probably not deliberately faking him out lends the irony a double edge while at the same time risking putting the entire essay beyond the pale of academic courtesy.

Derrida makes a rather belabored and elaborate joke almost at the end of Limited Inc. Here through the encroachment of the non-serious, Derrida makes what would normally be considered an entirely serious point: that there is something in common between the restrictive purity of theoretical discourse and the institutional restrictions imposed upon us in its "other" (not fully its other), the "real world." Yet once again, although Derrida does not like the notion of the ideological production of material institutions and vice versa in case it should smell too much of binary oppositions and isomorphism, the argument is welcome to ideology critics who would like precisely to call into question those classical constraints upon their practice. "At one moment or another [Searle] will notice that between the notion of responsibility manipulated by the psychiatric expert (the representative of law and of politico-linguistic conventions, in the service of the State and of its police) and the exclusion of parasitism, there is something like a relation" [pp. 78-79, 251; italics mine].

The conclusion itself is a collection of questions about seriousness, promises, and confrontations. Most serious disciplinarians find these gestures off-putting in published work. Why make such a thing of these marginal issues? It is because the delimiting and micro-structural exigencies of practice must be acknowledged constantly, persistently. "I have said only half in jest that women . . . understand a kind of work which does not ... lead to one's name in a bibliography or a totemized object like a book or one's proper name ... lingering in the pages of history. . . That sort of activity which simply repeats itself again and again and again, like keeping the house clean, is a sustaining political activity" [Spivak, in Spivak, Bill Galston, and Michael Ryan, "A Dialogue on the Production of Literary Journals, the Division of Disciplines and Ideology Critique," Analecta, 6 (1980), 84]. Without such interminable, inconclusive, and sustaining repetitions, theory forgets that it is also a practice, that it is at all times normed by that which it excludes; and begins to freeze, or to rot. As for example, this very binary opposition between theory and practice.

The final (non)serious item that I shall record is that Derrida manages to quote the entire Signature Event Context in Limited Inc. As I have said before, one of Derrida's pervasive arguments is that Searle unwittingly proves Derrida's points while seemingly opposing him. In that sense, "Reply to Derrida" is also a species of iteration/citation of Sec. In its legending, then, Limited Inc is a parodistic double session of iterability.

A practically fractured yet persistent critique of the hidden agenda of ethicopolitical exclusion; a sustained though necessarily fragmented stand against the vanguardism of theory; and, most importantly, a call to attend to the ever-askew "other" of the traditional disciplines; the need persistently to analyze that "confronta- 
tion," to figure out and act upon that "something like a relationship" between "ideology" and "social producation" which, ever non-self-identical, will not keep us locked in varieties of isomorphism. These are enabling principles for more than a constant cleaning-up (or messing-up) of the language of philsophy, although the importance of this latter is not to be underestimated. If the "other that is not quite the other" were to be conceived of as political practice, pedagogy, or feminism-simply to mention my regional commitments-one might indeed look for "'revolutions' that as yet have no model" [p. 72, 243].

The full sentence in fact runs: ". . 'literatures' or 'revolutions' that as yet have no model." The inclusion of literature seems consonant with the sustained justification of the avant-garde that often seems to be the task of the best in European criticism. Yet Derrida's usefulness for practice is not neutralized by such an association. I shall explain myself by way of a European critic who wrote powerfully in support of the avant-garde and drew a careful distinction.

Following Bertolt Brecht's own theories, Walter Benjamin described the former's theatrical experiments as a calling into question of the ideology of identity of the socalled Aristotelean stage, a stage that was politically and economically, as well as culturally, a restrictive norm upon twentieth-century European theatre. The identity in question is not merely "the purging of the emotions through identification with the destiny which rules the hero's life" ["What is Epic theatre?" (second version), in Understanding Brecht, tr. Anna Bostock (London: New Left Books, 1973), p. 18]. It is also the representational identification of the stage with reality, actor with role, and finally the identification of the proper and intrinsic space of dramaturgy by the strategic exclusion of its politico-economico-ideological "other" which underwrites its being.

Within the rich field of Brecht's theatrical imagination, the item whose pedagogic power Benjamin singles out reminds us of citationality or iterability. Just as Derrida insists that no speech act is, even originarily, tied to its appropriate context; and that thus iterability disrupts the so-called unity of voice and intention even as it remains the condition of possibility of form; so also Benjamin writes: "Interruption is one of the fundamental methods of all form-giving. It reaches far beyond the domain of art. It is, to mention just one of its aspects, the origin of the quotation. Quoting a text implies interrupting its context. . . 'Making gestures quotable' is one of the essential elements of epic theatre. The actor must be able to space his gestures as the compositor produces spaced type" [Benjamin, p. 19].

An extended consideration of Derrida's graphic of iterability and its undermining of self-identity on the one hand, and Brecht's iteration of gestures and its undermining of self-identity on the other, would involve at least a consideration of Derrida's early essay on Artaud ["The Theatre of Cruelty and the Closure of Representation," Writing and Difference, tr. Alan Bass (Chicago: Univ. of Chicago Press, 1978)] and his many comments on "spacing" as a critique of presence. ("Spacing (notice that this word speaks the articulation of space and time, the becoming-space of time and the becoming-time of space) is always the unperceived, the nonpresent, and the nonconscious. . . Arche-writing as spacing cannot occur as such within the phenomenological experience of a presence" [Crammatology, p. 68].) Here, however, I am more interested in the contrast that Benjamin exposes between Brecht's practice, which can be pedagogic, and Romantic Irony, which it superficially resembles. It seems to me that Derrida's position is to grasp iterability as the condition of possibility of the positive which will, however asymmetrically and unrigorously, result in the remains of a consensus; it therefore behooves us to forge theories (practices) of practice (theory), to whatever degree both are "normed" by the minutest detail of their structuring. In this, I place him with Brecht in Benjamin's discussion. American deconstruction, however, resembles what Benjamin writes of Romantic Irony; I choose one passage among many: "[The actor] must be free, at the right moment, to act himself thinking (about his part). It would be a mistake, at such moments, to draw a parallel with Romantic irony. . . . This has no didactic purpose; in the final analysis, all it demonstrates is the philosophical sophistication of the author, who, while writing his 
plays, always has at the back of his mind the notion that the world may, after all, be just a stage" [Benjamin, pp. 21-22]. Indeed, the genius of American deconstructivism finds in Romanticism its privileged model: "One may well wonder what kind of historiography could do justice to the phenomenon of Romanticism, since Romanticism (itself a period concept) would then be the movement that challenges the genetic principle which necessarily underlies all historical narrative. The ultimate test or 'proof' of the fact that Romanticism puts the genetic pattern of history in question would then be the impossibility of writing a history of Romanticism" [de Man, p. 82]. The self-transcendent trope is, indeed, Romantic Irony, as extended by the proper heir: "In a slight extension of Friedrich Schlegel's formulation, it becomes the permanent parabasis of an allegory (of figure), that is to say, irony. Irony is no longer a trope but the undoing of the deconstructive allegory of all tropological cognitions, the systematic undoing, in other words, of understanding. As such, far from closing off the tropological system, irony enforces the repetition of its aberration" [de Man, pp. 300-301; italics mine]. Rather than forging an irreducibly fragmented, untotalizable, yet "positive" or "affirmative" (words often used by Derrida) practice, such formulations as the above, as I have tried to show in my discussion of the structural unconscious and Reading, would remind us of nothing more than the inevitability of a repetition automatism, the repetition, in fact, of an aberration. The scenario is dramatized in the words I have italicized: after the lesson of deconstruction (the substitution-consciousness of "that is to say," "in other words") comes the "irony" of the iron fist ("as such," "enforces"). Because critics from the left and the right tend to see in deconstruction nothing but this itinerary of skepticism, any attempt, on the part of deconstruction, to disturb the status quo of theory is dismissed as "a certain Byronic chic. . . . Deconstruction ... is cogent enough to induce an occasionally felt scruple, but not a determination to change one's ways" [Denis Donoghue, "Deconstructing Deconstruction," NYRB, 27, No. 10 (1980), 41].14

For a more specifically political (if not in every detail) deconstructive practice of theory, one should perhaps turn to the "life" and "work" of Antonio Negri. I should like to end with the account of a humble pedagogic benefit that I receive from Derrida's generalized analogy.

Graduates and undergraduates alike seem caught in a doctrine of individual uniqueness. In a de-historicized academy, they find no difficulty in claiming their opinions' center as their own self-possession. This is matched by the ease with which collectivities in the third person are assigned centralized unitary descriptions: the fifties, the sixties, the seventies; Romanticism, Structuralism, Phenomenology. In the meantime, even in the most superficial and minimal analysis, one of the most striking characteristics of any version of advanced capitalism is the fragmentation and decentralization of the individual's putative political and economic control over her own life. One of the peculiar and paradoxical by-products of this system is to generate a conviction of individual centrality among most members of the intellectual, bourgeois, as well as managerial classes - "the internal regulation of the capitalist system which must limit concentration and decision-making power in order to protect itself against its own "crisis'" [p. 57; 226], accompanied by either a dispirited anguish against "their" power, or a spirited faith in "our" proliferation, with assorted permutations and combinations, of course. The official philosophy of this group is an individualism more or less disguised as pluralism. The generalizable result: lack of any conceivable interest in a collective practice toward social justice, or in recognizing the ethico-politically repressive construction of what presents itself as theoretical, legal, benign, free, or natural. The "deconstructive" lesson, as articulated in Limited

\footnotetext{
${ }^{14}$ On the other hand, serious and well-meaning sympathizers might also be overlooking an important point when they insist that deconstruction belongs to the philosophical tradition and should not be trifled with by people from other disciplines. What they might be recuperating is the impulse to confront the "other" of philosophy, not as the other as such. I am thinking of, say, David Carroll, "History as Writing," Clio, 7 (1978), 443-444, 459-66); and of Rodolphe Gasché's recent influential essay "Deconstruction as Criticism," Glyph 6.
} 
Inc, can teach student and teacher alike a method of analysis that would fix its glance upon the itinerary of the ethico-political in authoritarian fictions; call into question the complacent apathy of self-centralization; undermine the bigoted elitism (theoretical or practical) conversely possible in collective practice; while disclosing in such gestures the condition of possibility of the positive. My point here, I suppose, is that the range and risks of such a morphology (whose examples cannot match its discourse) can go rather further than a new school of literary-philosophical criticism, or even a mere transformation of consciousness. 